Natural Hazards and Earth System Sciences, 5, 763-775, 2005

SRef-ID: 1684-9981/nhess/2005-5-763

European Geosciences Union

(C) 2005 Author(s). This work is licensed

under a Creative Commons License.

\title{
The 30 December 2002 landslide-induced tsunamis in Stromboli: sequence of the events reconstructed from the eyewitness accounts
}

\author{
S. Tinti, A. Manucci, G. Pagnoni, A. Armigliato, and F. Zaniboni \\ Dipartimento di Fisica, Settore di Geofisica, Università di Bologna, Bologna, Italy \\ Received: 14 March 2005 - Revised: 25 July 2005 - Accepted: 25 July 2005 - Published: 10 October 2005 \\ Part of Special Issue "Tsunami hazard from slope instability"
}

\begin{abstract}
On 30 December 2002 the coast of the volcanic island of Stromboli, in the Tyrrhenian sea, Italy, was attacked by two tsunamis generated by landslides that took place on the north-west flank of the volcano. The landslides and the tsunamis represented the most impressive and threatening episodes of a strong effusive eruption, started on 28 December from a new vent which opened close to the north-east crater of the volcano. In spite of the intensified monitoring carried out in response to the eruption, the landslides and the ensuing tsunamis were not foreseen, and the available instrumental data are insufficient to allow a precise reconstruction of the sequence of the events. The seismic network recorded two main landslides along the steep slope of Sciara del Fuoco, with onset around 13:15 and 13:23 local time (GMT+1). The tsunamis were the direct consequence of the mass movements. Three main post-event surveys helped make assessment on the wave impact on the coast.

In this paper the attention is focussed on the accounts of the eye-witnesses, that help us clarify and understand what happened. People in the source area (Sciara del Fuoco) reported a small-volume subaerial slide taking place first, then a sharp cut forming in the sea water down to the sea floor (about 10-20 $\mathrm{m}$ deep) and propagating almost parallel to the coastline, be concomitantly associated with a sea retreat and a subsequent sea advance. It is suggested here that the cut was the effect of a large submarine landslide that detached from very close to the coast and produced the 13:15 signal in the recorded seismograms. The second, mostly subaerial, slump was observed to slide down 7-8 min later and to excite a train of waves some distance offshore. Not all the witnesses realised that two distinct tsunamis occurred. The tsunami period was probably in the order of $100 \mathrm{~s}$, but shorter period crests were seen to travel on the top of the long-period waves by several persons. The duration of each tsunami was appreciated to be around $5-7 \mathrm{~min}$. It is difficult to ascertain
\end{abstract}

Correspondence to: $\mathrm{S}$. Tinti

(steve@ibogfs.df.unibo.it) which tsunami was the largest, since there is no full agreement among the observers, but certainly by accounts both were characterised by large destructive waves.

\section{Introduction}

Stromboli is the northernmost island of the Aeolian archipelago in the southern Tyrrhenian sea (Fig. 1). It represents the summit of a large composite volcano, built up in the last $100 \mathrm{ka}$ and rising about $2.6 \mathrm{~km}$ above the sea bottom (e.g. Pasquarè et al., 1993; Tibaldi et al., 2003). Stromboli's volcanic behaviour has been adopted as the paradigm for one of the main volcanic eruptive styles, usually referred to as "strombolian activity". It is a persistent activity, consisting in regular mild explosions occurring every 15-20 min and lasting for few seconds. The typical products ejected during the bursts include incandescent material, ash and blocks, which can be thrown to heights of few tens to hundreds of meters above the craters (e.g. Rosi et al., 2000). Effusive eruptions at Stromboli are uncommon events, the last before 2002 dating back to December 1985 (De Fino et al., 1988). Stromboli edifice has been affected by several sector collapses in recent geologic history, the last of which occurred in the Holocene and originated the Sciara del Fuoco (SdF) scar in the northwest flank. Since the ejecta of the volcano are still preferentially channelled along the SdF, the scar has been progressively refilled by effusive lava and pyroclastic products so as to form the present-day very steep flank that is close to the angle of repose of loose, cohesionless material.

After a period of intensified strombolian activity from the summit 3-crater region, which increased from May 2002 onward, on 28 December 2002 the activity of Stromboli turned into an effusive phase. The change coincided with the opening of a big eruptive fissure, about $300 \mathrm{~m}$ long, that broke the northern wall of Crater 1, the North-East crater (Fig. 2; see Bonaccorso et al., 2003; Calvari et al., 2005). 
Table 1. Available information on the Stromboli December 2002 landslides and tsunamis.

\begin{tabular}{|c|c|c|}
\hline Type of data & Source (reference) & Comment \\
\hline Seismic recordings & $\begin{array}{l}\text { Bonaccorso et al. (2003) } \\
\text { La Rocca et al. (2004) } \\
\text { Pino et al. (2004) }\end{array}$ & $\begin{array}{l}\text { Analysis of the seismic signals associated with the } \\
\text { complex landslide sequence and with the tsunami } \\
\text { wave impact on the coasts }\end{array}$ \\
\hline Orthophoto & Baldi et al. (2003) & $\begin{array}{l}\text { Orthophoto and DTM of the island of Stromboli. Pre- } \\
\text { and post-event data comparisons: estimation of the } \\
\text { landslide volumes }\end{array}$ \\
\hline Thermal surveys & $\begin{array}{l}\text { Bonaccorso et al. (2003) } \\
\text { Calvari et al. (2005) }\end{array}$ & $\begin{array}{l}\text { Mapping and reconstruction of the lava flows and of } \\
\text { the surface cracks on SdF }\end{array}$ \\
\hline Multibeam surveys & Chiocci et al. (2003) & $\begin{array}{l}\text { Multibeam and Side Scan Sonar bathymetric surveys } \\
\text { offshore SdF: estimation of the subaqueous landslide } \\
\text { volume }\end{array}$ \\
\hline Field surveys & $\begin{array}{l}\text { Maramai et al. (2005a) } \\
\text { Tinti et al. (2005a) }\end{array}$ & $\begin{array}{l}\text { Tsunami run-up and inundation measurements at } \\
\text { Stromboli; run-up and observations in the Aeolian } \\
\text { archipelago and in the far-field }\end{array}$ \\
\hline Video recordings & Dr. Massimo Pompilio & $\begin{array}{l}\text { Video sequences documenting the first small sub- } \\
\text { aerial landslide (SL1) and tsunami waves attacking } \\
\text { Punta Labronzo }\end{array}$ \\
\hline Panarea tide gauge & This study & $\begin{array}{l}\text { Comment on the (poor) information on the tsunami } \\
\text { deducible from the tide gauge record }\end{array}$ \\
\hline Interviews & This study & $\begin{array}{l}\text { Reconstruction of the two main landslides and of the } \\
\text { two tsunamis based on eye-witness accounts }\end{array}$ \\
\hline
\end{tabular}

In the following two days, thermal surveys carried out by the INGV-CT team allowed to document abundant and discontinuous lava flows from two lateral vents that formed on the SdF below the summit craters at the altitude of $600 \mathrm{~m}$ and $500 \mathrm{~m}$ (Bonaccorso et al., 2003). On 30 December, at about 11:30 local time, smoke and vapour rising from a well-defined linear fracture bounding a triangular portion of the SdF flank were clearly documented and shot during a helicopter-borne survey (see Fig. 2c of Bonaccorso et al., 2003). Two hours later a large-volume mass failure took place in two main distinct episodes: large-amplitude water waves were generated, that attacked Stromboli and Panarea (Fig. 1) and were seen in the whole Aeolian archipelago.

The main goal of the present paper is to reconstruct the sequence of these events, namely the mass failure and the subsequent tsunamis, that occurred on 30 December based on the accounts of eye-witnesses who were in Stromboli and in Panarea at the time of the disaster. Their testimony is precious and necessary to clarify how the facts evolved, and complements the evidence resulting from the instrumental monitoring network as well as from surveys that were carried out by researchers in the following days and weeks. Interviews of the eyewitnesses are used here mostly to understand what happened in the crucial interval of 15-20 min embrac- ing the occurrence of the main landslides and the generation of the tsunamis, and serve to elucidate the main dynamics of the process that cannot be univocally and clearly deduced from the other available data. The main problem concerns the distinction between the first and the second main landslides and their individual characterisation. Post-event surveys could only observe the cumulative effects of both landslides, while the accounts of the eyewitnesses give us invaluable clues, and enable us to reach some relevant conclusions. In this paper we will give evidence that the first slide originated underwater, while the second detached in the subaerial portion of SdF.

\section{State of the art}

With the aid of Table 1, we summarise here the available instrumental data for the 28 December 2002 events, and the studies that have already been published or are under publication. The seismic network consisting of short-period, intermediate-period and broad-band stations, managed by different sections of INGV (i.e. INGV-CT, INGV-OV and INGV-CNT), recorded two distinct signals on 30 December 2002 , that were attributed to two landslides, probably characterised by complex multiple sliding. From the analysis 


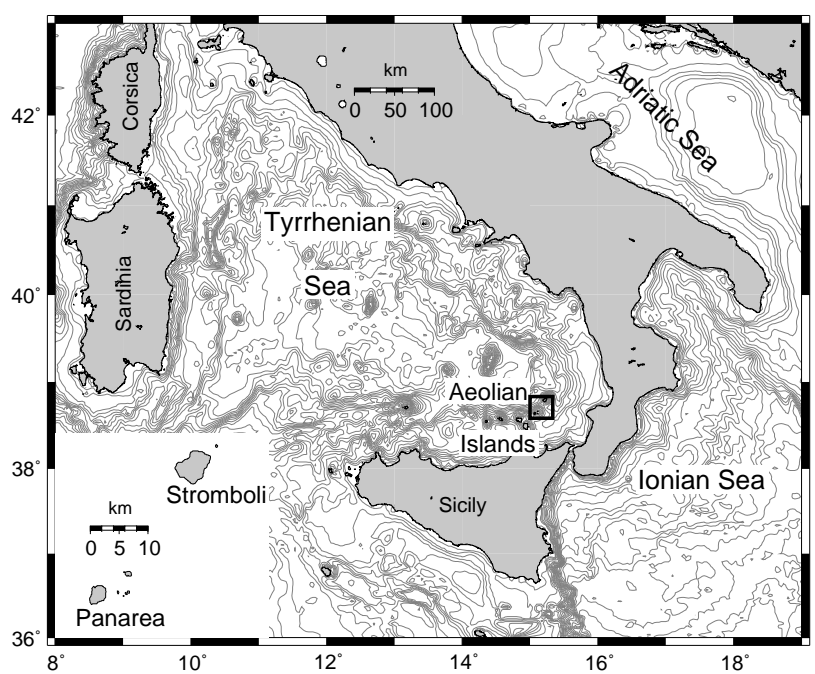

Fig. 1. Geographic map of central-southern Italy, showing the location of the Aeolian archipelago. Stromboli is the northernmost island of the group. Panarea is about $20 \mathrm{~km}$ far to SSW of Stromboli.

of short period seismograms, the first onset was seen at 13:14:05, and the second at 13:22:38 (local time) (Bonaccorso et al., 2003; Pino et al., 2004). Further, high amplitude low-frequency signals are well identified on the broad-band records in Panarea, starting at 13:15:00 and at 13:22:40 (La Rocca et al., 2004).

Two scars are clearly visible on the northern subaerial flank of the SdF from pictures taken on 31 December (Bonaccorso et al., 2003). These were probably mostly produced by the second complex episode of mass failure. Comparative analyses of pre-failure and post-failures aerophotos, respectively taken in 2001 and 6 days after the events, led to estimate that the missing volumes in the subaerial portion of SdF were in the range of $10^{7} \mathrm{~m}^{3}$ (Tommasi et al., 2003; Baldi et al., 2003).

Numerous bathymetric MULTIBEAM and Side Scan Sonar (TOBI and MAK-1) surveys were performed offshore $\mathrm{SdF}$ after a few days. Comparison with data taken about one year earlier shows that the two subaerial scars were merging in a unique scar under the sea level and that the total missing volume could be estimated to be around $2-3 \times 10^{7} \mathrm{~m}^{3}$ (Chiocci et al., 2003).

Interestingly, Stromboli was characterised by an uninterrupted eruptive activity causing lava flows and mass sliding to occur frequently and to affect topography and bathymetry remarkably in the SdF area for several days (Baldi et al., 2003). Hence, computing the volumes involved in the 30 December main failures is not an easy task and estimates may be uncertain.

The effect of the excited tsunami was disastrous in Stromboli and damaging in Panarea. The maximum penetration of the waves as well as the run-up was still identifiable on vegetation and constructions some weeks after the disaster. Several post-tsunami surveys were performed by national and

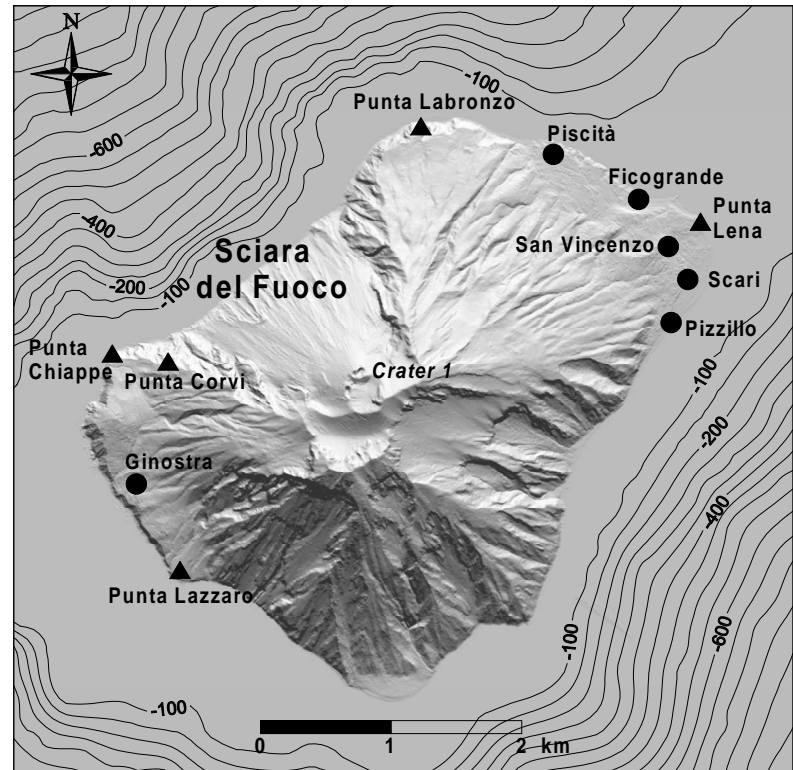

Fig. 2. Map of Stromboli, reporting the toponyms quoted in the text, from a DTM provided by P. Baldi. The deep morphological scar of the Sciara del Fuoco (SdF) is evident in the north-western flank of the volcano.

international scientific teams and confirmed that the run-up heights were unequal in the southern and northern coast of Stromboli. The most affected coastal segment was the one from Piscità to Ficogrande and Punta Lena with values exceeding 9-10 m, with large variations of the measured run-up height values observed over short distances (Maramai et al., 2005a; Tinti et al., 2005a).

Strangely enough, what we know instrumentally on the tsunami comes from the island of Panarea, located some $20 \mathrm{~km}$ to SSW of Stromboli (Fig. 1). Unfortunately, the instrumental information is poor. In the port of Panarea, that is found on the eastern coast, a tide gauge was installed and was functioning at the time of tsunami arrival, but it was calibrated to measure slow and small-amplitude sea level changes possibly connected to some volcanic deformation centre offshore Panarea. It was jointly operated by INGVCNT (Rome) and by ISMAR-CNR (Bologna). The 5-min sample interval and the negative amplitude cut at $-40 \mathrm{~cm}$ did not allow it to record the tsunami satisfactorily. However, it was possible to ascertain that at 13:24 the tsunami was already arrived at Panarea, that at 13:29 the sea exceeded its normal level by more than $1 \mathrm{~m}$, and that the tsunami perturbation lasted for several hours. Three coastal three-component broad-band stations operated by INGV-OV were also installed in Panarea. As already mentioned, they recorded the landslide signals. Fortunately, they also recorded the impact of the tsunami against the coast of Panarea. More precisely they recorded the ground displacement induced by the tsunami attacking the coast (La Rocca et al., 2004). From the analysis of these signals, it is possible to infer that the tsunami attacked the northern coast of Panarea, the closest 
Table 2. Summary of the Eye-Witnesses Locations and Observations reported in the paper. SL1 indicates the small subaerial landslide observed at 13:11 (local time), L1 and L2 the two main landslides recorded by the seismic network at 13:14:05 and at 13:22:38 respectively, and $\mathrm{T} 1$ and $\mathrm{T} 2$ the first and the second tsunami.

\begin{tabular}{llcccccc}
\hline Eye-witness & Location & Figure & Seen SL1 & Seen L1 & Seen L2 & Seen T1 & Seen T2 \\
\hline Gualtiero Grassi & SdF, Punta dei Corvi (point G) & 3 & $\mathrm{~N}$ & $\mathrm{Y}$ & $\mathrm{Y}$ & $\mathrm{Y}$ & $\mathrm{Y}$ \\
Massimo Pompilio & SdF, points $P_{1}, P_{2}$ & 3 & $\mathrm{Y}$ & $\mathrm{N}$ & $\mathrm{Y}$ & $\mathrm{N}$ & $\mathrm{Y}$ \\
Emanuele Famularo & Piscità & 4 & $\mathrm{~N}$ & $\mathrm{~N}$ & $\mathrm{~N}$ & $\mathrm{Y}$ & $\mathrm{N}$ \\
Mario Fabrizio & Piscità & 4,5 & $\mathrm{~N}$ & $\mathrm{~N}$ & $\mathrm{~N}$ & $\mathrm{Y}$ & $\mathrm{N}$ \\
Matteo Scibilia & Ficogrande & 4 & $\mathrm{~N}$ & $\mathrm{~N}$ & $\mathrm{~N}$ & $\mathrm{Y}$ & $\mathrm{Y}$ \\
Nino Zaccone & Ficogrande & 4 & $\mathrm{~N}$ & $\mathrm{~N}$ & $\mathrm{~N}$ & $\mathrm{Y}$ & $\mathrm{N}$ \\
Pasquale D'Ambrosio & Ficogrande & 4 & $\mathrm{~N}$ & $\mathrm{~N}$ & $\mathrm{~N}$ & $\mathrm{Y}$ & $\mathrm{N}$ \\
Philippe Guillemin & Scari & 6 & $\mathrm{~N}$ & $\mathrm{~N}$ & $\mathrm{~N}$ & $\mathrm{Y}$ & $\mathrm{Y}$ \\
Stefania Dante & Scari and Pizzillo & 6 & $\mathrm{~N}$ & $\mathrm{~N}$ & $\mathrm{~N}$ & $\mathrm{Y}$ & $\mathrm{Y}$ \\
Angelina Dante & Scari & 6 & $\mathrm{~N}$ & $\mathrm{~N}$ & $\mathrm{~N}$ & $\mathrm{Y}$ & $\mathrm{N}$ \\
Claudio Utano & San Vincenzo & 6 & $\mathrm{~N}$ & $\mathrm{~N}$ & $\mathrm{~N}$ & $\mathrm{Y}$ & $\mathrm{Y}$ \\
Maria Boeti & San Vincenzo & 6 & $\mathrm{~N}$ & $\mathrm{~N}$ & $\mathrm{~N}$ & $\mathrm{~N}$ & $\mathrm{Y}$ \\
Paolo De Rosa & Pizzillo & 6 & $\mathrm{~N}$ & $\mathrm{~N}$ & $\mathrm{~N}$ & $\mathrm{~N}$ & $\mathrm{Y}$ \\
Gianluca Giuffrè & Ginostra & 2 & $\mathrm{~N}$ & $\mathrm{~N}$ & $\mathrm{~N}$ & $\mathrm{Y}$ & $\mathrm{N}$ \\
Salvatore Petrusa & Ginostra & 2 & $\mathrm{~N}$ & $\mathrm{~N}$ & $\mathrm{~N}$ & $\mathrm{Y}$ & $\mathrm{N}$ \\
Carola Tesoriero & Panarea & 1 & $\mathrm{~N}$ & $\mathrm{~N}$ & $\mathrm{~N}$ & $\mathrm{~N}$ & $\mathrm{Y}$ \\
Maurizio Ferrara & Panarea & 1 & $\mathrm{~N}$ & $\mathrm{~N}$ & $\mathrm{~N}$ & $\mathrm{~N}$ & $\mathrm{Y}$ \\
\hline
\end{tabular}

one to Stromboli, at about 13:20, and that it took $2 \mathrm{~min}$ to reach the station in the south. We also deduce that the tsunami period is in the order of 100-120 s. In some seismic records, the arrival of the second tsunami seems to be identifiable from a change in the signal phase that is found about 7 min later, and seems to have magnitude comparable with the first one.

Eventually, we provide here a short outline of the physiography of Stromboli to help the reader follow easily the descriptions reported in the following sections. In Stromboli there are two main villages: the small village of Ginostra located in the south-west high-cliff corner, and the village of Stromboli stretching in the north-eastern area, comprehending several hamlets, such as San Vincenzo, the main centre that is built high on the sea, and the coastal hamlets of Piscità, Ficogrande, Punta Lena, Scari and Pizzillo. West of Piscità, the northern coast is characterised by a long beach mostly with pebbles, boulders and rocks called Spiaggia Longa. Between Piscità and Ficogrande there is a series of small pocket beaches separated by rocky promontories. Larger pebbly beaches characterize the north-east corner of the island. The beach morphology is subjected here to a strong dynamics, and it changes frequently especially in winter, as storms cause severe sediment erosion or accumulation according to the waves direction.

\section{Interviews of witnesses}

We collected tens of interviews from people in Stromboli and in Panarea during a number of campaigns in the field in early 2003. The main difficulties in finding and meeting witnesses was initially due to the restrictions posed by civil protection authorities to accessing Stromboli, since the island was considered under the menace of a new impending disaster: all residents and tourists were evacuated, and only operators and officials of the civil protection as well as scientists involved in surveys and monitoring had permit to stay, together with local people engaged in emergency activities. Only several weeks after the events residents were allowed to come back home, though some restrictions for climbers on the Stromboli summit and for navigation in the SdF area did and still do continue to hold.

The questionnaire was adapted following the IOC/UNESCO post-tsunami survey field guide (IOC/UNESCO, 1998). After the identification of the most significant interviews, selected eyewitnesses were contacted for a second and more detailed interview, that was conducted either orally (direct contact or by phone) or through email, with the purpose of clarifying some points of their accounts (such as possible misunderstanding on the precise meaning of some words or circumlocutions). The highest attention was always given to elucidate what they really saw and to avoid that interviewees be influenced by interviewer's opinion, which is a principle at the basis of the science of questionnaire design and of survey research (Conrad and Schober, 2000; Schaeffer and Presser, 2003).

For the purpose of this article we selected 17 witnesses, whose interviews were grouped on the basis of their geographic location at the time of the events (Figs. 2-4, and 6). Table 2 is a summary of the detailed reports that are discussed in sections 4 through 7 . We introduce the following convention: SL1 will indicate the small subaerial landslide observed at 13:11 (local time), L1 and L2 the two main landslides recorded by the seismic network at 13:14:05 and at 


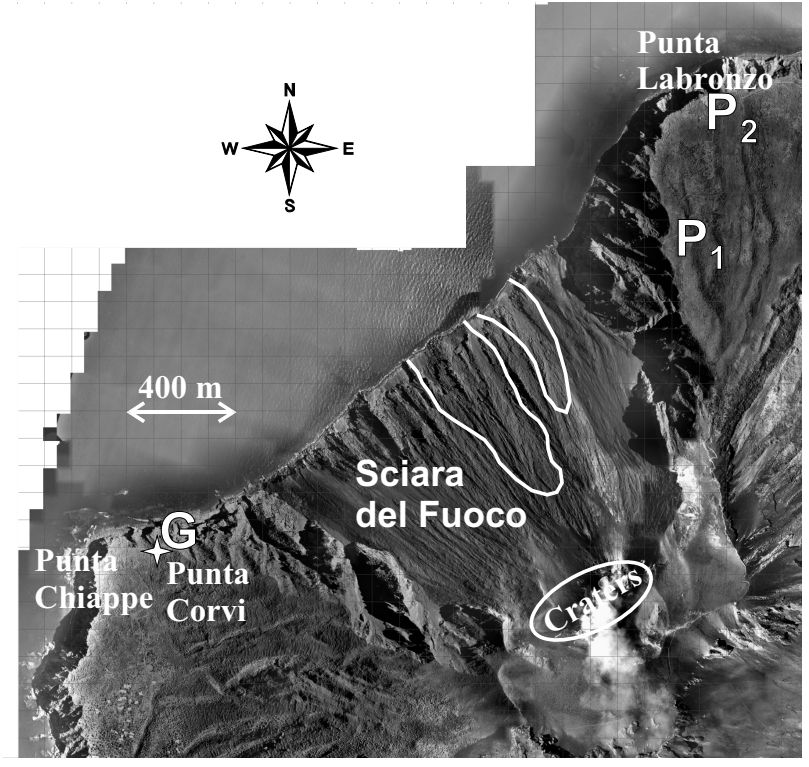

Fig. 3. Orthophoto of the Sciara del Fuoco. Mr. Grassi observed the events from Punta dei Corvi (marked by G), on the southern margin of SdF. Dr. Pompilio was at the point $P_{1}$ until the slide of $13: 11$, then moved to point $P_{2}$. In the SdF, the boundary of the scars that were photographed by INGV-CT on 31 December are sketched (Bonaccorso et al., 2003). Orthophoto provided by P. Baldi.

13:22:38 respectively, and $\mathrm{T} 1$ and $\mathrm{T} 2$ the tsunamis generated by the main landslides.

\section{Accounts on the landslides}

Two people were close to the area of the SdF at the time of mass failures: Dr. Massimo Pompilio, a researcher of INGV$\mathrm{CT}$ and Mr. Gualtiero Grassi, who lives in the island for a fair part of the year. Their positions at the time of the landslides and tsunamis are shown in Fig. 3.

\subsection{The Sciara del Fuoco seen from the north}

Dr. Pompilio was on duty in Stromboli to study the eruption. In the morning of 30 December he was on the path from Punta Labronzo to the craters, and was observing the lava flow from the northern side of the SdF approximately at the altitude of $300 \mathrm{~m}$ a.s.l. (point $P_{1}$ in Fig. 3). He used a digital videocamera to document the events that occurred since 11:00 a.m. local time. His movie begins with the phase preceding the failure: lava flowing from the vent around $450-500 \mathrm{~m}$ altitude, blocks rolling downslope and splashing in the sea, incandescent material entering the sea, that caused phreatic explosions and ascending high clouds of water vapour. One of such vapour columns was documented to occur at around 11:55 a.m. Dr. Pompilio was also able to capture the opening of the fracture bounding the top part of the impending failure at about $500 \mathrm{~m}$ altitude.

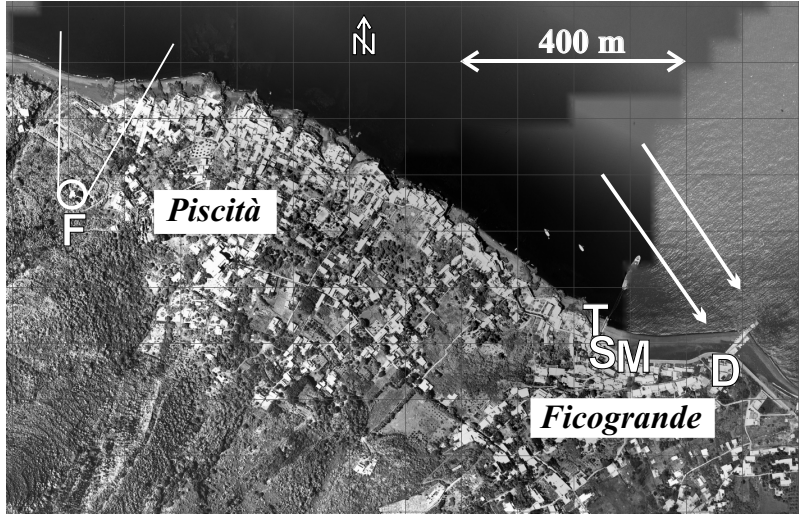

Fig. 4. Orthophoto (P. Baldi) of the northern coast of Stromboli, from Piscità to Ficogrande. Mr. Famularo and Mr. Fabrizio (point F) observed the tsunami from the house at the center of the white circumference (on the left). The beach of Ficogrande is visible on the right side. The letters $\mathrm{T}, \mathrm{S}$ and $\mathrm{M}$ mark the respective positions of the restaurant La Tartana, and of the hotels La Sirenetta and Miramare, reported in the accounts of Mr. Scibilia and Mr. Zaccone. White arrows show the direction of the waves, according to Mr. Scibilia. On the right side of the beach, the letter D shows Mr. D'Ambrosio's place.

At about 13:11 a loud rumble announces the occurrence of a dark-colour small landslide that is recorded in the movie only for about $4-5 \mathrm{~s}^{1}$. Seen from Dr. Pompilio's place the mass flow occurs in the foreground while the lava with the associated vapours is in the background. The head of the landslide impacts the sea surface and advances seaward very fast, while the rear material accumulates quickly on the material ahead and grows very high over it. The movie stops suddenly here, since Dr. Pompilio ran prudently to a safer place, the Punta Labronzo restaurant (Point $P_{2}$ in Fig. 3).

Dr. Pompilio resumed filming some minutes later at 13:21 from $P_{2}$, that was however less favourable to capture the $\mathrm{SdF}$ events, since the SdF slope was hidden from his sight. During the 10 min gap, he missed the first tsunami. In the movie, dense white and grey clouds rise from the SdF area and are deflected by the south-west winds towards the houses of Stromboli. Just 1 min after Dr. Pompilio had started filming again, dark clouds rose from the $\mathrm{SdF}$, creating the impression that they were due to a mass falling seaward. Dr. Pompilio then pointed the camera towards the sea. The movie shows first that there is a zone near the coast around Punta Labronzo where the sea water was already abnormally muddy (in our view, as the consequence of the first tsunami) and second, that a turbulent wave front attacked Punta Labronzo and then travelled towards Piscità (and this is the second tsunami).

1 This short piece of movie is publicly available on the web at: http://www.ct.ingv.it/Stromboli2002/GeoVulca/Filmati/ hotavweb.mov. 


\subsection{The Sciara del Fuoco seen from the south}

It was around 09:00 a.m. when Mr. Grassi moved from Ginostra to a place named Punta dei Corvi to enjoy the natural spectacle of the eruption (point G in Fig. 3). He remained there for several hours until the occurrence of the failures and of the subsequent tsunamis. He was observing the scene from the southern side of the $\mathrm{SdF}$, at a quote of about $100 \mathrm{~m}$ a.s.l. Owing to the irregular and convex shape of the SdF slope, the lava flow and its coastal entry were partly out of his sight. Mr. Grassi observed carefully all the events from Punta dei Corvi and his account is precious since it integrates and complements Dr. Pompilio movie. Unfortunately he had no camera and we have to rely upon his words. He confirms the events seen by Dr. Pompilio until midday, including the $500 \mathrm{~m}$ vent opening. The only difference is that he could not identify the splashes of stones and hot material entering the sea. He only saw water spurts and vapour columns, and presumed they were the effect of explosions originated within the sea, due to opening of numerous submarine vents.

Mr. Grassi could not provide the exact timing of the events, but remembers their chronological order clearly. Interestingly, he reports of a substantial increment of the lava flow intensity and of the number of large blocks rolling down, then he narrates of a sort of a knoll forming at the sea level, but he mentions no slide occurrence. What was that knoll? We think that Mr. Grassi saw the 13:11 slide impacting on the sea surface, seen by Dr. Pompilio just before running to Punta Labronzo, but he misinterpreted it as the growth of a volcanic cone near the shoreline. This mistake can be explained by the fact that the slide was partly hidden to his sight because of the SdF morphology and further because, from his viewpoint, it occurred behind the white dense vapours rising from the lava flow.

Mr. Grassi's further description concerns events that were not seen by Dr. Pompilio who was moving away from the SdF leaving the main scene behind his shoulders. These events are crucial to understand the generation of the tsunamis and it is worth quoting some excerpts from Mr. Grassi's interview here below. "Starting from a few meters offshore, the sea suddenly opened and the water showed to me a wall that was initially blue and then became darker and darker as the opening was coming deeper. It was a sort of a vertical cut in the water. The opening originated where the knoll formed and the lava penetrated the sea. How much the cut propagated towards Punta Labronzo, I cannot tell since it was hidden by clouds. Instead, I can tell that it propagated towards my place. The cut speed was not too fast. It was following the margin of the underwater platform that from offshore SdF gets to Punta Chiappe. My attention was drawn by the cut coming towards me. The cut reached the sea bottom that remained uncovered. I know that close to Punta Chiappe the sea depth is about $10-15 \mathrm{~m}$. The cut widened, though not too much. Then the water came back. The wave attacked the cliff. The wave against the cliff was not exceptionally high. Probably it reached the same height as during large storms. In summary, the sea was first devoid of water, and then filled again."

The above descriptions concern the first mass failure and the first tsunami. The tsunami was not seen during the phase of the knoll formation, i.e. of the subaerial landslide shot by Dr. Pompilio, but it was generated soon afterwards. Mr. Grassi description goes on as follows. "From the SdF slope a lot of material and lava blocks continued to fall down and large dust clouds were rising from $\mathrm{SdF}$ and blown away from my side towards Stromboli. Then suddenly the SdF collapsed down as a unique block. For a second or so, I did not understand and I thought that the SdF slope was not sliding down and that, instead, the clouds were moving uphill... But it took very short to realise what truly was taking place. There was a loud noise. The ground shaked. Then the water was pushed seaward. I saw a train of waves generated some distance offshore. The slide moved as when one shovels away sand from the basis of a heap sand. It slid down, it did not roll". Mr. Grassi did not move from his point of observation, since he thought that Punta dei Corvi is a stable place outside the SdF scar, and evaluated that the slide could involve at most the SdF slope. "After the slide, a number of other explosions occurred, but in an hour or so everything smoothed down and $\mathrm{SdF}$ became quite. For some time after the slide, it seemed as if material was rising to the surface from the sea bottom up to about $700-800 \mathrm{~m}$ offshore in front of the SdF, and seagulls were particularly excited and flew grazing the sea water".

\section{Reconstruction of the tsunamigenic landslides}

The accounts reported above show some apparent discrepancies. However, a critical analysis can help resolve. Dr. Pompilio saw a landslide entering the sea at about 13:11, looking at it for a few seconds, before he stopped filming. When he resumed $10 \mathrm{~min}$ later, he documented white dust clouds probably produced by rocky material sliding downslope, dark clouds rising from low altitude close to the sea surface, and eventually he saw waves attacking the cape of Punta Labronzo. In summary, he saw one subaerial landslide and one tsunami. On the other hand, Mr. Grassi, though being unable to specify timing, saw the following sequence of events: the formation of a knoll; a cut in the sea water down to the sea floor, that originated approximately where the knoll formed and grew parallel to the coast; the fall and subsequent rise of the sea surface; the sliding of the SdF slope into the sea, the generation of a train of sea waves. In summary, he saw two tsunamis and one subaerial landslide. In our opinion, the joint analysis of these reports, leads us to the following reconstruction.

1. The landslide seen by Dr. Pompilio and the knoll seen by Mr. Grassi are the same phenomenon. Indeed, in the 4-5 s during which one can see the landslide in Dr. Pompilio's movie, the head of the landslide does not penetrate in the sea, but seems to travel over the sea surface and grow high quite fast. Hence, it is credible that Mr. Grassi, who could not see the area perfectly, 
made an error of interpretation. This mass flow did not generate a visible tsunami. In our opinion, this was a very pellicular movement involving only a very thin and light-material layer of the subaerial slope, probably in the same region that was later affected by the northern scar photographed in the following day by INGV-CT (sketched in Fig. 3). However, for the reasons only just exposed, we believe that this landslide was not the main responsible of that scar.

2. The cut in the water was the most striking manifestation of the first tsunami. It was likely caused by a large submarine landslide that nobody could see. The occurrence of a large submarine landslide could be perfectly reconciled with what Mr. Grassi observed. It is known that slides moving underwater tend to produce positive waves in the front and negative waves in the rear (Tinti and Bortolucci, 2000a, 2000b; Ward, 2001). We infer that a submarine landslide detached underwater very close to the coastline, approximately where the previous thin subaerial landslide reached the sea. Bathymetric surveys conducted a few days after these events confirmed the existence of a deep scar, along the submerged part of the SdF, with maximum mass deficit found in shallow water area (Chiocci et al., 2003) where the water cut was seen to originate by Mr. Grassi. This submarine landslide was probably the one detected in the seismograms at about 13:14-13:15 and likely generated the first tsunami. Overloading caused by lava and material accumulation close to the coastline, i.e. at the base of the subaerial portion of SdF, and overpressure due to phreatic explosions can be reasonably considered as the causes of the submarine mass mobilisation.

3. The submarine slide increased the instability of the subaerial part of $\mathrm{SdF}$, and was accompanied and followed by a series of smaller failures along the slope, responsible of the clouds that were pushed towards Stromboli by the strong south-west winds. These failures were not tsunamigenic, in the sense that they did not cause waves large enough to travel around Stromboli, but only local splashes and water agitation.

4. The big subaerial slide seen by Mr. Grassi was responsible for the second tsunami, that was also filmed by Dr. Pompilio. On the basis of timing considerations, we believe that this is the slide recorded by seismic stations around 13:22-13:23. It is certainly the principal cause of the larger scar photographed by INGV-CT on 31 December (Fig. 3), and detached from the fissures opened at least $2 \mathrm{~h}$ before at $500 \mathrm{~m}$ altitude along the slope, documented by Dr. Pompilio (see also Bonaccorso et al., 2003).

\section{Accounts on the tsunamis}

Dr. Pompilio and Mr. Grassi were the only persons near SdF at the time of the mass failures and tsunami generation. All other interviewees were far from SdF and observed the abnormal excitation of the sea, the water retreat, the coastal flooding, etc. In other words, they are eye-witnesses of the tsunamis, and some of them found themselves in great danger since they were on the point of being carried away or being drowned in the waves. In the following the interviews are classed according to the place where the people were at the time of the tsunami.

\subsection{Piscità}

Mr. Mario Fabrizio and Mr. Emanuele Famularo were in a house located in the westernmost part of Piscità, $200 \mathrm{~m}$ from the coast (Fig. 4). Mr. Fabrizio heard a loud noise at 13:15 and thought it was due to an earthquake, then he looked at the sea and saw a sea disturbance coming from Punta Labronzo, that caused a water retreat by about $30-40 \mathrm{~m}$. The retreat happened three times, and each time it was accompanied by a big ash cloud rising in the sky. Mr. Fabrizio declared that the first wave was the weakest. On the contrary, Mr. Famularo said that the first wave was the most powerful, but not the highest: the water withdrew, picked up sand, rose like a wall and then started propagating as an organized wave. The second and third wave looked like swelling. Mr. Fabrizio estimated in 30-40 s the time gap between the waves, and in 3-4 min the total duration of the phenomenon, before the sea became quiet again. From the house, Mr. Fabrizio took some pictures of the waves starting from shortly before the beginning of the tsunami attack. Two photos (Fig. 5) show the tsunami initial retreat (Fig. 5a), that leaves part of the seafloor uncovered (in particular some sea-bottom rocks), and the subsequent water advance (Fig. 5b).

\subsection{Ficogrande}

Ficogrande is the hamlet placed at the beginning of the flat part of Stromboli village. From here the street linking Piscità to the pier of Pizzillo begins to run low and parallel to the coast. The orthophoto shown in Fig. 4 helps locate the relevant places mentioned in this section. The beach of Ficogrande is $30-40 \mathrm{~m}$ wide and $220-240 \mathrm{~m}$ long. It is delimited by the restaurant La Tartana to the west and by an old (dismissed) pier to the east. Behind the street there are hotels, houses and shops. The most important buildings are the hotel La Sirenetta and the hotel Miramare, that is built on higher ground behind a first row of houses. The two hotels are separated by public steps that climb towards San Vincenzo. In Ficogrande the tsunami damage was very severe: many houses were destroyed and a large amount of sand was removed from the beach and partly deposited inshore. The main eyewitnesses here were Mr. Matteo Scibilia, Mr. Nino Zaccone and Mr. Pasquale D'Ambrosio.

Mr. Scibilia and his brother Enrico were driving their motor scooters along the seafront towards Scari. They noticed volcanic clouds in the sky, and stopped close to the hotel La Sirenetta to see what was happening. As the cloud reached the sea, the sea began swelling with a loud noise and 


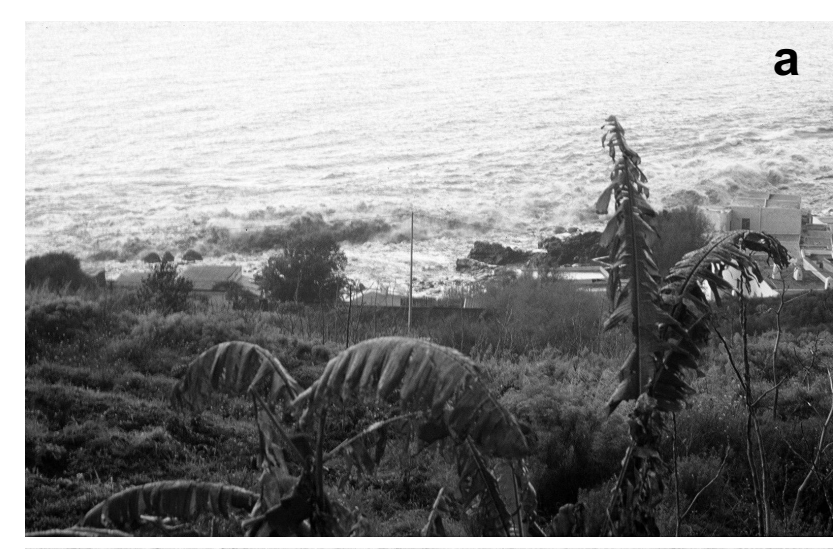

b

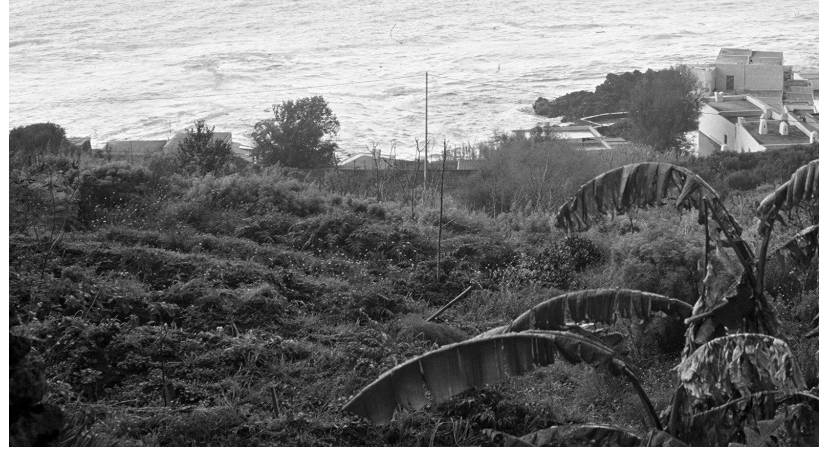

Fig. 5. Photos of the tsunami attacking seafront houses in Piscità, taken by Mr. Fabrizio from Mr. Famularo's home. The corresponding visual angle is drawn white in Fig. 4. The tsunami caused the water to retreat from the coast first (a), and then to come back (b). Mr. Fabrizio could not see the shoreline from his point of observation, that is $200 \mathrm{~m}$ away from the beach.

retreating from the coast, and then a big wave went back. The wave was advancing from Piscità with a front oblique with respect to the beach. Frightened, they left their scooters below the hotel Miramare and escaped uphill along the public steps. The wave overtopped the terrace of La Tartana, fell down into the street and was channelled there. The hotel La Sirenetta reception was seriously damaged and the water left dead fish in the street. The wave reached the 21st step of the public path, about $7 \mathrm{~m}$ high a.s.l. and hurled the scooters by $20 \mathrm{~m}$ inside the hotel Miramare. Mr. Scibilia realised that he had seen a tsunami, though from the noise he heard, he was expecting much bigger waves. Mr. Scibilia states that he observed a second tsunami after a time gap of $5 \mathrm{~min}$. He counted four main waves for the first tsunami and three for the second. The most powerful wave was the first, since it appeared as a high wall of water, while the others slid and climbed up the first. The second tsunami was also characterised by a sequence of water retreats and advances, but the first wave was the less powerful and the last one the highest.

Mr. Nino Zaccone was driving a scooter along the seafront, when the Scibilia brothers warned him about the danger. He looked at the sea and noticed that the water had already in- vaded half of the beach (he missed the first water retreat). Then, he escaped reaching the safe place where the two brothers had already found shelter. His report confirms Mr. Scibilia's account, adding only a few details. The noise was like rolling stones. The second sea retreat uncovered the sea floor down to the submerged old hydrofoil wharf, located in front of La Sirenetta, about $6 \mathrm{~m}$ deep and $40 \mathrm{~m}$ offshore. He saw three distinct waves in all. He estimated in $45 \mathrm{~s}$ the time gap between the first and the second wave and in 20-25 s the gap between the second and the third. The total duration of the phenomenon was about $3 \mathrm{~min}$. He gave us an evaluation of the run-up values: the first wave reached $6-7 \mathrm{~m}$ in height; the second one was less than $4 \mathrm{~m}$; the third had a $2 \mathrm{~m}$ height. He did not see the second tsunami.

Mr. Pasquale D'Ambrosio was near his house, in the second row of houses on the eastern side of Ficogrande beach (Fig. 4). He did not see the first wave. Around 13:15 he just heard a noise like stones colliding against each other. Scared, he hurried home to rescue his daughter. Running precipitously from the house with the child, he fell from the balcony hurting his ankle. He saw the second wave 25-30 s after the first, and it seemed to him as a water wall about $12 \mathrm{~m}$ high. The water invaded the ground floor of his house. He saw a third wave. The ash cloud followed the three waves.

\subsection{Scari}

Scari is a long pebble beach going from the cape of Punta Lena, the north-east corner of the island, to the zone of the main pier. The pier is called Pizzillo in the official maps, but most local people know it as Scari as well. The seafront street, mentioned in the previous section, continues here almost straight running parallel to the beach after a right turn at Punta Lena (Fig. 6). On the beach, some private houses and small villas have been built in the course of the recent years. Behind the street, one finds some residential buildings and public structures, the most important of which is the electric power plant that provides energy for the whole population of Stromboli island, except the residents of Ginostra. The main eyewitnesses in this zone are a French photographer, Philippe Guillemin, Miss Stefania Dante and her mother, Angelina. These people found themselves in danger since they were attacked by the waves flooding the coast.

Mr. Guillemin was walking along the street with two friends near the electric power station (Fig. 6). He recognised the occurrence of two distinct tsunamis, the first more or less at 13:15, the second about $10 \mathrm{~min}$ later, at 13:25. The weather was initially good, and the volcano summit seemed to be covered by a smoke cloud. Then they saw a great white plume rising and expanding fast in the sky together with a brown-colour cloud. From the street, they saw the tsunami flooding the beach and the street behind them. Frantically they ran away to escape the wave and reached a higher place on the other side of the street. The first wave swept away everything and overtopped the street by about $1 \mathrm{~m}$. A second wave suddenly followed (a few seconds later). Mr. Guillemin told that this second wave was not as big as the first one, 
but it had a greater run-up because it slid over the first and met no obstacles. In some photos he had the spirit to take, a tsunami wave is shown running along the street. From this safer place, Mr. Guillemin and his friends observed what occurred later. About 1 min after the end of the tsunami, lapilli started falling down in two distinct phases. The second rain was more intense. The clouds were not very dense since one could see the sun through them. The group saw the second tsunami $10 \mathrm{~min}$ after the first and estimated that it was probably stronger. The sea swelling hit the coast nearby the power plant. They distinguished the attack of two waves. Next, a black huge plume descended the flanks of the volcano towards San Vincenzo, which was plunged into semi-darkness and was hit by a rain of grains and lapilli. The plume was transported by the wind over the sea.

Mrs. Angelina and her daughter Miss Stefania Dante were at home: they live in a house about $20 \mathrm{~m}$ a.s.l. behind the electric power station. They saw the first wave arriving around 13:15. They inferred the time, considering that they saw the wave while the passenger boat, that was scheduled for that time, was leaving Pizzillo. Both were worried about the destiny of Mr. Dante who they supposed to be working at the beach, and therefore at great risk. Hence, they decided to go and rescue him. Actually, Mr. Dante was elsewhere, away and absolutely safe from the tsunami, but they did not know. Mrs. Angelina jumped on her scooter and drove towards the beach of Scari. Here she left the scooter and walked. She was reached by a wave. The water rose up to her knees, and she hardly withstood the strength of the current by grasping at something firm, maybe a fence. But she cannot remember precisely. After the water withdrew, she walked towards the electric power station. It could have been 13:20, but she had no watch. Meanwhile, in search for her father, Stefania ran from home towards the pier of Pizzillo. Looking at the sea, she saw a water wall $8-10 \mathrm{~m}$ high. At the INGV site, which is beyond the street, just south of the power plant (Fig. 6), she was reached by the wave up to her knees. She saw the wave attacking the power plant area and a group of foreigners escaping from the water. Probably, she saw Mr. Guillemin and friends. Then, she went to Pizzillo, where she heard a noise like a spin-dryer and noticed a sea retreat. Afraid of a second incoming wave, she sheltered at the ticket office in front of the pier, whence she saw some little waves coming from Ficogrande, travelling beyond the pier and taking away some boats (Fig. 6). She remained at the ticket office for $10 \mathrm{~min}$ after these events, but she did not see any further perturbation in the sea. In our opinion the two women saw the first incoming tsunami from their house and were both attacked by it, though in different places. Further Miss Stefania Dante saw the second tsunami when she was in Pizzillo.

\subsection{San Vincenzo}

San Vincenzo lies on the volcano flank higher than Ficogrande (Figs. 2 and 6). It dominates the north-east corner of the island. From the village square one can enjoy a splendid view of the coast from the offshore rock of Strombol-

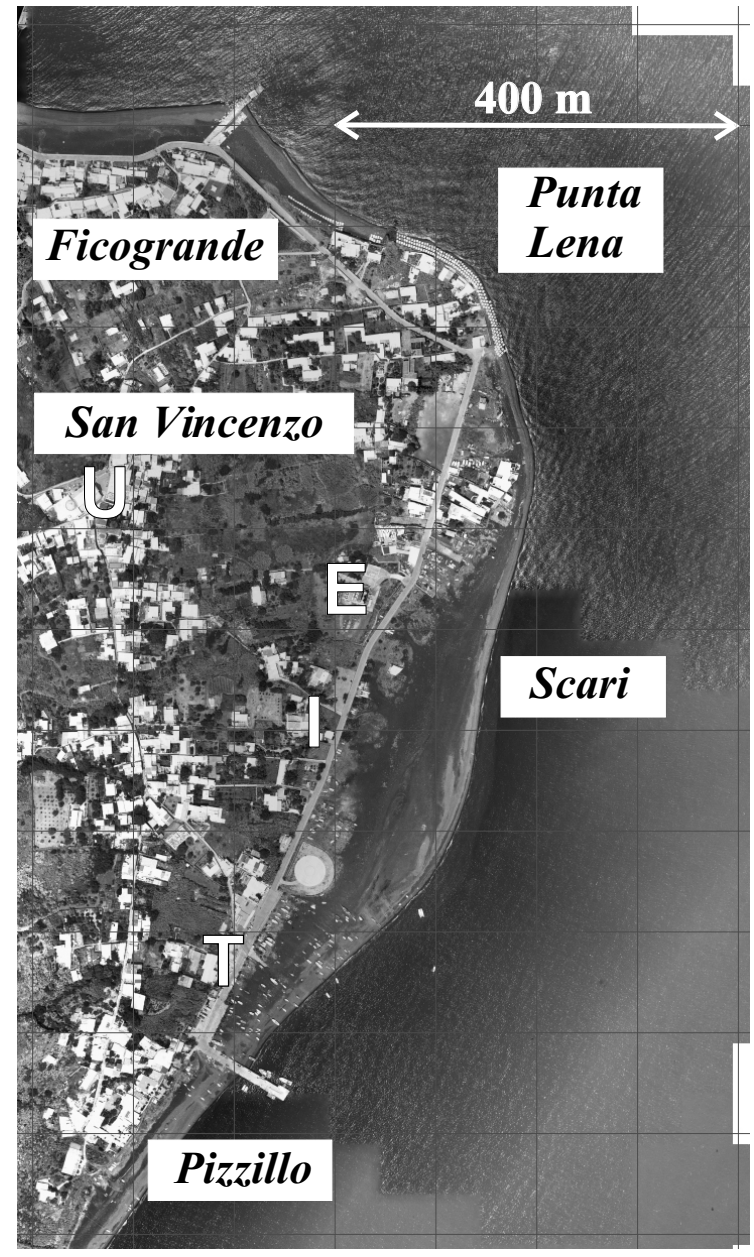

Fig. 6. Orthophoto of the north-eastern corner of Stromboli. The panoramic view point at the square of San Vincenzo from which Mr. Utano and Mrs. Boeti saw the tsunami is marked by the letter $\mathrm{U}$. The places of the electric power station (E) and of the INGV site (I) are found along the main street in Scari. Also shown is the position of the port ticket office in Pizzillo, that is mentioned in Miss Dante's report (T).

icchio, fronting the Ficogrande beach, to Punta Lena, Scari and Pizzillo. There are two main eye-witnesses that saw the events from this privileged point of view: Mr. Claudio Utano who was at home and rushed to the square to have a look and to take photos; and Mrs. Maria Boeti, who runs a shop in the square. They were spectators with no fear of being affected by the waves, since they were feeling to be in a very safe place.

Mr.Utano's home is near San Vincenzo square. He was watching TV when he heard a strange noise and there was an electric black out. It was around 13:20 (note that, according to the electric company files, the black out occurred at 13:18:25). The noise increased. He rushed out and saw his brother working on the roof in the front house. From the roof, his brother noticed that the sea was perturbed. Mr. Utano joined the brother on the roof to have a look himself: 
he got the impression that the water was boiling, that the sea level rose and some waves were forming. Neither of them realised that it was a tsunami, but they first thought that the water was boiling due to the lava flowing into the sea. Mr. Utano left his brother on the roof, rushed home and caught the camera. He saw the sea retreating towards SdF and forming a wave. While he was running to the square (Fig. 6) to have a better look, the sea came back. The time interval since the blackout to his arrival at the square was probably of 2$3 \mathrm{~min}$. He noticed that Mrs. Boeti was already in the square. About 3 min later he saw the sea boiling again. He took the pictures of four waves in all, the first two coming from SdF, the second being like a wall, the third coming from the opposite direction and the fourth coming from SdF again. He could not distinguish the two tsunamis, but had the feeling of a continuous excitation of the sea. From the time he took the first picture, the sea excitation lasted ca. 5-6 min.

At 13:10-13:15, Mrs. Boeti closed the shop for the lunch break and headed to the scooter she had parked behind the church facing the square. She was on the point to switch it on, when she heard a loud noise reminding her the noise of stones rolling down SdF, but louder. She looked at the sky and saw two clouds, one black and one white moving towards the square. She met a tourist and together they went to the panoramic terrace of the square. They saw a wave coming from Piscità. Its front was initially perpendicular to the coast, then it turned almost parallel. Simultaneously, another wave was coming from Pizzillo. The two waves collided, and the water rose and hit the coast in front of the electric power plant. Mrs. Boeti saw the sea flooding the area around the plant. After this occurrence, a fallout of ash and mud began. She remained and observed the sea for half an hour, but she did not notice any further relevant perturbations. It is not clear to us which tsunami Mrs. Boeti described in her interview. Probably she saw the second. She narrates of only one tsunami attack to the power station. But we know from Mr. Guillemin that it was attacked by both tsunamis. And pictures of the second were also taken by Mr. Utano.

\subsection{Pizzillo}

Pizzillo is the most important embarking/landing place for the public and private traffic of the island (Fig. 6). In addition to the already cited account by Miss Stefania Dante, we obtained some information on the tsunami attack in Pizzillo by Mr. Paolo De Rosa. He was at his mother's home. She observed and told him of a quite strange low tide. But he overlooked her notice. Only about 2-3 min later he looked at the sea and saw a first train of coming waves. The sky was clear. Then he saw an ash cloud and the transit of a second train of waves.

\subsection{Ginostra}

Ginostra is a little village in the south-west of Stromboli island, built on a cliff (Fig. 2). It has a little harbour built in a natural creek, where only small boats, like rubber boats, can moor. A little square dominates the harbour and here was Mr. Gianluca Giuffrè. The other eyewitness was Mr. Salvatore Petrusa, the owner of the restaurant and bar located higher.

Mr. Giuffrè was at home. He lives behind the shop where he works near the square. He heard a strange noise, like something frying or boiling. He went out and saw the sea retreating, he dashed down the square and noticed that the water retreated up to the "shark" rock, $40 \mathrm{~m}$ offshore. Then the wave came back slowly towards the coast like a tide, rose and covered all the pier taking some ships away. At first, $\mathrm{Mr}$. Giuffrè did not realise how high the wave was. It rose over the brick wall in the harbour, maybe $7-12 \mathrm{~m}$ high, $10 \mathrm{~m}$ on average. Water retreats and advances repeated five times at least: the first wave was very violent, then it became weaker and weaker, and the last one was very weak. After the first two waves, he went to the church and call for other people. Then he came back to the square. In total, the perturbation lasted some 5-7 min.

Mr. Petrusa was also at home. His house is behind his restaurant above the little square. It was 13:15. He was watching the TV news when he heard a noise which made the windowpanes vibrate. He thought the noise was caused by the ferry-boat manoeuvre, since it was more or less the time it disembarks passengers at Ginostra. The noise was louder than usual and made him go out and run to the square. Once arrived there, he saw a 25-30 m sea retreat for a long stretch of coast up to Punta Lazzaro to east of Ginostra (Fig. 2). He did not look to his right (i.e. towards $\mathrm{SdF}$ ) and hence missed what happened on that side of the coast. He observed three sea retreats and advances, which occurred in about $15 \mathrm{~min}$, with time gap between waves of 6-7 min. However, he knows that the waves were four and that he missed the first one. All of them were coming from south-west. The first he saw inundated the quay, but did not reach the brick wall. The following were weaker. He immediately realised that it was a tsunami.

\subsection{Panarea}

Panarea is an island of the Aeolian archipelago, some $20 \mathrm{~km}$ to SSW of Stromboli (Fig. 1). In Panarea, the tsunami caused some damage, mostly in the harbour. We interviewed here the owners of the bar "Da Carola", that resulted the building most affected by the tsunami. Mrs. Carola Tesoriero and her husband Mr. Maurizio Ferrara were at home, from which they can see the harbour. They received a phone call from the waiter at the bar, who told that something dangerous was happening and that he was hearing like a stone noise. The waiter told that, as he went outside, he saw the sea rising and ran away to find a safer place. Mrs. Tesoriero reported that she received the phone call at 13:00, while her husband stated it was 13:20, which seems to be more correct. While Mrs. Tesoriero was going to the bar down to the harbour, she saw the sea to retreat maybe $100 \mathrm{~m}$. Frightened, she ran home again to her son and alerted her neighbours, who all escaped to higher places. She remembered well the noise of the rising sea. 
After the first wave attack, Mr. Ferrara was informed on the telephone by the waiter that everything inside the bar was upside down. While Mr. Ferrara was going from home to the bar, he saw the sea to retreat, leaving the harbour completely dry. He could not reach his bar since the street was obstructed by several boats carried onshore by the previous wave. When the water came back to refill the harbour, the current was rather strong and formed clockwise eddies. The water overtopped and swept the quay. It was not like a wave, but rather as a strong tide. Lowering and rising of the harbour level repeated 5-6 times. The mark the water left on the wall near the door of the bar was $1 \mathrm{~m}$ high, whereas inside the bar the water mark was at $2 \mathrm{~m}$ height. Here the tsunami destroyed all the furniture and damaged the walls.

\subsection{Reconstruction of the tsunami events}

Inferring the tsunami dynamics from the accounts reported above is not simple, because they are partially discordant and contradictory. On the other hand, some differences in the reports are justified by the expected different behaviour of the tsunami in different places along the coast. Before analysing the content of the accounts, it is convenient to make a general remark concerning the knowledge these people had of a tsunami. People of Stromboli are certainly familiar with marine waves and storms. Some of the residents were also aware that Stromboli had been hit by some tsunamis in the last century, as it is reported in tsunami catalogues (Tinti and Maramai, 1996; Tinti et al., 2004). And, moreover, some past tsunamis happen to have interesting similarities with the events of 2002 (Maramai et al., 2005b). But none of the interviewees had a direct experience of a tsunami, neither of a double tsunami. Therefore, it is not surprising that some eye-witnesses did not immediately realise that a tsunami was occurring.

We remark that, in addition to Mr. Grassi, only two eyewitnesses are sure to have observed two distinct tsunamis, $\mathrm{Mr}$. Scibilia in Ficogrande and Mr. Guillemin in Scari at an interval of about 5-10 min. To be more precise, they are sure they observed two distinct sequences of waves, that we can interpret as two distinct tsunamis, the second coming on the queue of the first. We note that Mr. Scibilia and Mr. Guillemin were both in a very good observation position, because they happened to be close to the sea from the very beginning and, once they found a safer place, they had to remain there until the hazard ended. As for the others, either they saw both tsunamis without distinguishing the first from the second, or they saw only one, mostly only the second since they came late to their observation place.

For the first tsunami, Mr. Scibilia (Ficogrande), Mr. Giuffrè (Ginostra), Mr. Fabrizio (Piscità) and Mr. De Rosa's mother (Pizzillo) saw first the sea to retreat from the coast. Moreover, Mr. Fabrizio took a series of pictures (see Fig. 5) showing the tsunami approaching the coast of Piscità and uncovering the seafloor there. This is compatible with the observations made by Mr. Grassi in the source region, and leads further evidence in favour of a submarine landslide gener- ation mechanism. Probably nobody could appreciate with clarity the first manifestation of the second tsunami (flooding or retreat), since it occurred while the sea was still perturbed by the first one. Mr. Scibilia hade the sensation that the sea retreated for a while. Dr. Pompilio captured some images of the second tsunami attacking Punta Labronzo. Even from his movie, the initial tsunami wave cannot be identified with certainty, while the high turbulence of the water, and the sea rising and forming a steep crest can be seen clearly. These were probably common features for both tsunamis and explain why the sea seemed to be boiling and swelling to most people.

About the estimate of the wave period and the wave number, a remark has to be made first. The tsunamis were probably characterised by long period oscillations (swelling and rising of the sea surface) and of small period waves (crests, breaking waves) travelling on the top of them. This complex wave dynamics is influenced strongly by very local morphological sea-bottom conditions. A well-formed crest with a front almost perpendicular to the coast was pictured by $\mathrm{Mr}$. Utano travelling between Punta Lena and Scari. A breaking wave like a water wall was also photographed by Mr. Utano when attacking Punta Lena cape. For the eyewitnesses it was hard to make specific estimates for these different waves. Mr. Guillemin estimated only a few seconds between the first and the second flooding waves at Scari: certainly the second wave was a short-period crest that travelled on the top of the first wave and could penetrate deeper inland.

The figures of the time intervals between waves go from 20-30 s (Mr. Zaccone at Ficogrande and Mr. Fabrizio at Piscità) to more than $5 \mathrm{~min}$ (Mr. Petrusa at Ginostra). From tsunami simulations carried out by using landslide sources in the order of $10-30 \times 10^{6} \mathrm{~m}^{3}$ in $\mathrm{SdF}$ the main wave period results to be in the order $10^{2} \mathrm{~s}$ (Tinti et al., 2005b). Ground displacements recorded by the broadband seismometers installed in Panarea exhibit main periods of the same order of magnitude (La Rocca et al., 2004).

Also the figures of the number of waves vary from case to case. For example, at Ficogrande, Mr. Scibilia counted four waves for the first tsunami and three for the second, while Mr. Zaccone, who was in the same place, remembers only three waves, that were probably of the first tsunami. Mr. Guillemin distinguished two waves for both the first and the second tsunami attacking Scari. From the view terrace of San Vincenzo's square, Mr. Utano described and photographed four waves. Probably Mr. Utano observed the first tsunami from the roof of his house and the second tsunami from San Vincenzo square. Therefore he counted and documented the waves of the second tsunami. Interestingly, he captured the moment immediately before the collision of the two interfering waves that attacked the power station, and that was also reported by Mrs. Boeti. The colliding waves were coming from the north and from the south. We believe that they were edge waves, that originated at the $\mathrm{SdF}$ and propagated from there in both directions going around the island of Stromboli. The existence and persistence of edge waves around circular islands is a well-known subject in the literature (see 
e.g. Tinti and Vannini, 1995), and that it could be an expected occurrence for Stromboli was already anticipated by Tinti et al. (2000) who simulated a tsunami due to a mega-collapse of the SdF.

Very likely, both tsunamis were powerful and destructive. At Ficogrande, probably the first tsunami was more violent than the second. Mr. Scibilia reports that the first wave attacked the restaurant La Tartana, and then the buildings beyond the seafront, and Mr. Zaccone estimated a 6-7 m wave height in the place he was standing. According to Mr. Guillemin, the second tsunami was possibly larger than the first at Scari close to the electric plant where he was. Therefore, the plant was probably flooded by both. According to Mr. Utano's pictures, that, as already mentioned, show an impressive high wave attacking the houses at the waterfront of Punta Lena, the second tsunami had also potential to be disastrous, at least on some coastline segments of the island. The damage caused by the double tsunami resulted to be very severe all along the coast from Piscità to Scari, and many houses were damaged or destroyed there. Around Pizzillo no damage was documented to the houses and only some beached boats were carried somewhat inland by the waves and slightly damaged.

\section{$7 \quad$ Timing}

Discrepancies in timing are not surprising because of the different nature of these sources, namely instrumental and human. The seismograms recorded by the seismic stations installed in Stromboli and in Panarea provide time values that fit the scientific standards and are therefore of high reliability. Equally reliable is the time read in the sea level recorded by the tide-gauge installed in the port of Panarea. From these sources we know that two main landslides detached at 13:15 and at 13:22-13:23 local time, that the tsunamis hit north Panarea around 13:20 and 13:27 (broad-band signals), and that the tsunami arrived at the Panarea harbour between 13:19 and 13:24 (tide-gauge record).

A further source of timing is the clock of the digital videocamera used by Dr. Pompilio. Maybe its absolute time is affected by a bias, but time intervals separating different events have good reliability. We believe that the gap, during which Dr. Pompilio interrupted shooting, lasted about $10 \mathrm{~min}$ as the camera clock indicates. If there is a bias, it is quite small, since time provided by the camera when the movie shows the tsunami attacking Punta Labronzo is just the time we expect for a tsunami generated in the SdF by a landslide that detached at 13:22-13:23. Hence, we also believe that landslide SL1 occurred really around 13:11, that is some minutes earlier than the main submarine failure.

At the lowest level of reliability there are the time estimates given by the eye-witnesses, who used their watches or simultaneity with some other occurrences (TV programs, scheduled times of public boat lines, etc.) to make time evaluations. We know that the sequence of the events can be noticed and remembered by human beings much more than the time separation between them, especially when people are under psychological stress, such as fear of an imminent disaster implying risk for one's own life or excitement for the occurrence of an extraordinary event. And this aspect must be duly and properly taken into account to weigh the relevance of their accounts.

\section{Conclusions}

The accounts of the eye-witnesses of Stromboli and of Panarea were used to infer the sequence of events that caused destruction in Stromboli on 30 December 2002. We found evidence for a double tsunamigenic event. The first tsunami was caused by a submarine landslide detached from just below the shoreline of the $\mathrm{SdF}$ and the second tsunami was produced about 7-8 min later mainly by a landslide detached from above the sea level in the exposed flank of the SdF. Indeed the seismic records identify two distinct signals produced by distinct and complex mass failures, but they cannot be used to locate their source precisely. They tell us only that the signal radiated from sources placed in the $\mathrm{SdF}$, without resolving between submarine or subaerial origins (La Rocca et al., 2004). Moreover, aerophotogrammetric and bathymetric campaigns showed that large masses of rocks were missing along the SdF slope both above and below the water level, but establishing the number of failures and their chronological order is very hard (Chiocci et al., 2003; Baldi et al., 2003). Not all the episodes of instability that took place in the SdF were identified, but only two of them were large enough to produce sizeable tsunamis. Probably, between the 13:15 submarine landslide and the main 13:23 failures, a large number of smaller failures took place both underwater and from the emerged flank. The latter ones were likely the cause of the clouds visible in Dr. Pompilio's movie after 13:21 that were rising from the SdF and that many people saw later in Stromboli.

Eventually, we point out the importance of having ascertained that masses detaching from different points (above and below the sea surface) of the SdF have tsunamigenic potential in the optics of the civil protection. Indeed, this implies that the entire SdF flank has to be subjected to continuous monitoring with systems operating in land as well as offshore to detect precursors of failures timely wherever they occur, either underwater or onshore.

Acknowledgements. The authors are very grateful to all the people of Stromboli and Panarea who were interviewed and that contributed with very collaborative spirit to this research. We are also indebted to M. Pompilio for the discussions and comments we had together on the precious movie he recorded. We are also thankful to all colleagues who made their instrumental data available, namely to the researchers of INGV-CT, INGV-OV, INGV-CNT, of ISMAR-CNR, and to the scientific teams from the Universities of Roma "La Sapienza", University of Bologna, INGV-CT and ISMAR-CNR, who performed bathymetric and aerial surveys. In particular, P. Baldi of the University of Bologna provided us with the DTM and the orthophotos of the island of Stromboli, elaborated in the framework of the GNV Project n.13: 
"Sviluppo e Applicazione di Tecniche di Telerilevamento per il Monitoraggio dei Vulcani Attivi Italiani”. We wish to thank the Civil Protection people in charge and operators for logistic aid and advice. Eventually, we are grateful to A. Cattaneo for the thorough review of the paper. This work has been funded by INGV-GNV.

Edited by: H. Lee

Reviewed by: A. Cattaneo

\section{References}

Baldi, P., Belloli, F., Fabris, M., Marsella, M., Monticelli, R., and Signorotto, V.: La fotogrammetria digitale differenziale del versante della Sciara del Fuoco (isola di Stromboli) dopo l'evento del 30 Dicembre 2002, 7a Conferenza Nazionale ASITA "L'informazione territoriale e la dimensione del tempo", (in Italian), Verona, 28-31 October, 2003.

Bonaccorso, A., Calvari, S., Garfì, G., Lodato, L., and Patané, D.: Dynamics of the December 2002 flank failure and tsunami at Stromboli volcano inferred by volcanological and geophysical observations, Geophys. Res. Lett., 30, 18, 1941, doi:10.1029/2003GL017702, 2003.

Calvari, S., Spampinato, L., Lodato, L., Harris, A. J. L., Patrick, M. R., Dehn, J., Burton, M. R., and Andronico, D.: Chronology and complex volcanic processes during the 2002-2003 flank eruption at Stromboli volcano (Italy) reconstructed from direct observations and surveys with a handheld thermal camera, J. Geophys. Res., 110, B02201, doi:10.1029/2004JB003129, 2005. (Correction: J. Geophys. Res., 110, B04201, doi:10.1029/2005JB003723, 2005).

Chiocci, F. L., Bosman, A., Romagnoli, C., Tommasi, P., and De Alteriis, G.: The December 2002 Sciara del Fuoco (Stromboli Island) submarine landslide: a first characterisation. EGS-AGUEUG Joint Assembly, Nice, France, April 2003, Geophysical Research Abstracts, Vol.5, CDROM Version, 2003.

Conrad, F. G. and Schober, M.F.: Clarifying question meaning in a household telephone survey, Public Opinion Quarterly, 64, 1-28, 2000

De Fino, M., La Volpe, L., Falsaperla, S., Frazzetta, G., Neri, G., Francalanci, L., Rosi, M., and Sbrana, A.: The Stromboli eruption of 6 December 1985-25 April 1986: Volcanological, petrological and seismological data, Rend. Soc. Ital. Mineral. Petrol., 43, 1021-1038, 1988.

IOC/UNESCO: Post-tsunami survey field guide, Manuals and Guide No. 30 (First Edition), PDF version available online at: http://www.prh.noaa.gov/itic/library/pubs/glossary/tsunami_ field_guide_eng.pdf, 1998.

La Rocca, M., Galluzzo, D., Saccorotti, G., Tinti, S., Cimini, G. B., and Del Pezzo, E.: Seismic signals associated to landslides and tsunami at Aeolian islands, Italy, Bull. Seism. Soc. Am., 94, 1850-1867, 2004.
Maramai, A., Graziani, L., Alessio, G., Burrato, P., Colini, L., Cucci, L., Nappi, R., Nardi, A., and Vilardo, G.: Near- and farfield survey report of the 30 December 2002 Stromboli (Southern Italy) tsunami, Marine Geology, 215, 93-106, 2005a.

Maramai, A., Graziani, L., and Tinti, S.: Tsunami in the Aeolian islands (southern Italy): a review, Marine Geology, 215, 11-21, 2005b.

Pasquarè, G., Francalanci, L., Garduño, V. H., and Tibaldi, A.: Structure and geologic evolution of the Stromboli volcano, Aeolian Islands, Italy. Acta Vulcanol., 3, 79-89, 1993.

Pino, N. A., Ripepe, M., and Cimini, G. B.: The Stromboli volcano landslides of December 2002: A seismological description, Geophys. Res. Lett., 31, L02605, doi:10.1029/2003GL0118385, 2004.

Rosi, M., Bertagnini, A., and Landi, P.: Onset of the persistent activity at Stromboli Volcano (Italy), Bull. Volcanol., 62, 294-300, 2000.

Schaeffer, N. C. and Presser, S.: The science of asking questions, Annual Review of Sociology, 29, 65-88, 2003.

Tibaldi, A., Corazzato, C., Apuani, T., and Cancelli, A.: Deformation at Stromboli volcano (Italy) revealed by rock mechanics and structural geology, Tectonophysics, 361, 187-204, 2003.

Tinti, S. and Vannini, C.: Tsunami trapping near circular islands, Pure Applied Geophysics, 144, 595-619, 1995.

Tinti, S. and Maramai, A.: Catalogue of tsunamis generated in Italy and in Côte d'Azur, France: a step towards a unified catalogue of tsunamis in Europe, Annali di Geofisica, 39, 1253-1299, 1996 (Errata Corrige, Annali di Geofisica, 40, 781, 1996).

Tinti, S. and Bortolucci, E.: Energy of water waves induced by submarine landslides, Pure Applied Geophysics, 157, 281-318, 2000a.

Tinti, S. and Bortolucci, E.: Analytical investigation on tsunamis generated by submarine slides, Annali di Geofisica, 43, 519-536, 2000b.

Tinti, S., Bortolucci, E., and Romagnoli, C.: Computer simulations of tsunamis due to flank collapse at Stromboli, Italy, J. Volcanol. Geoth. Res., 96, 103-128, 2000.

Tinti, S., Maramai, A., and Graziani, L.: The new catalogue of Italian tsunamis, Natural Hazards, 33, 439-465, 2004.

Tinti S., Maramai A., Armigliato, A., Graziani, L., Manucci, A., Pagnoni, G., and Zaniboni, F.: Observations of physical effects from tsunamis of 30 December 2002 at Stromboli volcano, Southern Italy, Bull. Volcanol., in press, 2005a.

Tinti, S., Pagnoni, G., and Zaniboni, F.: The landslides and tsunamis of the 30 December 2002 in Stromboli analysed through numerical simulations, Bull. Volcanol., in press, 2005b.

Tommasi, P., Chiocci, F.L., Coltelli, M., Marsella, M., and Pompilio, M.: Analysis of the first data on the instability phenomena associated to the 2002-2003 Stromboli volcano lava flow eruption, Int. Symp. Flows, Sorrento, 15-16 May, 2003.

Ward, S. N.: Landslide tsunami, J. Geophys. Res., 106, B6, $11201-$ $11216,2001$. 